\title{
ANTHROPOLOGICAL AND PALEOPATHOLOGICAL ANALYSIS OF SKELETAL REMAINS FROM THE SITE OF MARGUM/MORAVA (POŽAREVAC, SERBIA), MEDIEVAL PERIOD - THE RESULTS OF THE EXCAVATIONS IN 2011
}

\author{
Nataša Šarkić \\ OSTEO Research, Spain \\ Teodora Branković \\ National Museum in Požarevac, Serbia \\ e-mail: nsarkic@gmail.com | Preliminary article \\ Received: 30. 4. 2020. UDC: 904:726.8]:572.7"653"(497.11) \\ Accepted: 23. 8. 2020. 902.2(497.11)"2011"
}

\begin{abstract}
The archaeological site of Margum/Morava, at the confluence of the Velika Morava into the Danube, was an important strategic point. The first traces of a settlement originate from the Neolithic period. This is the first anthropological analysis ever performed on the Margum/Morava material, although the site itself has been archaeologically investigated since the beginning of the $20^{\text {th }}$ century, and many burials were found, from Bronze Age, Roman times, Migration period, Byzantine period and the Middle Ages. The anthropological analysis published here presents the results of the excavations performed in 2011. Even though the number of graves analysed here is modest-a total of 8 graves (we took into account only non-devastated graves for this analysis), they produced exciting results that will help us shed light on the living conditions in this area. Most frequent changes on bones were the ones that can be connected with occupational stress, osteoarthrosis and dental diseases, but also fractures and infections resulting from injuries, metabolic stress and even two possible cases of tuberculosis.
\end{abstract}

Keywords: metabolic disease, infection, dental health, occupational stress, TBC, Pott disease, tuberculous spondylitis

\section{Introduction}

The archaeological site of Margum/Morava is located north of the village of Dubravica (Младеновић and Јацановић 2002, 221), at the confluence of the Velika Morava into the Danube. It is a multi-layer archaeological site with traces of life dating from the Early Neolithic (around 6000 BC) until the modern times. In the $1^{\text {st }}$ century BC, the Roman city - Municipium Aurelim Augustum Margum was located on this site (Mirković 1968, 50-51). Historical sources from the Late Antiquity often mentioned Margum/Morava as a target of various invaders of 
the Empire or a crossing point of the Roman troops into Barbaricum (Mirković 1986, 208-209). After the Hun conquest and the reign of Ostrogoths and Gepids in the $5^{\text {th }}$ century, the Eastern Roman Empire re-established their rule at the time of Emperor Justinian (527-565 AD) (Иванишевић and Бугарски 2012, 240). The collapse of defences at the Danube border of the Empire occurred in the first decades of the $7^{\text {th }}$ century. Since then, Margum/Morava hadn't been significantly inhabited for a long time. The reconstruction of the city on a reduced area took place from the end of the $9^{\text {th }}$ century, and layers of a settlement belonging to the $10^{\text {th }}-12^{\text {th }}$ century were also registered (Иванишевић and Бугарски 2012, 240). According to historical sources from the $11^{\text {th }}$ century from Morava (in the Middle Ages, instead of the Latin name "Margum" name "Morava" came into use), there was a city and an episcopal seat there (Пириватрић 1997, 173-201).

The position of Margum/Morava was first noted and published by Antonio Bonfini in his work on the Kingdom of Hungary, which was printed in 1543 (Bonfini 1543, 109). More detailed information about the site was provided by Felix Kanitz, at the end of the $19^{\text {th }}$ century, who noted that the site measured 820 x $720 \mathrm{~m}$ (Kanitz 1892, 13-16). Due to erosion caused by the river Velika Morava, in the first half of the $20^{\text {th }}$ century, a significant part of the site was destroyed.

The first archaeological excavations at this site were carried out in 1909 by Miloje Vasić, and a necropolis from the Late Bronze Age was investigated (Иванишевић and Бугарски 2012, 240). In the period from 1947 till 1954, archaeological excavations were organized by the Archaeological Institute and the National Museum in Belgrade (Мано-Зиси et al. 1950; Marić 1951). In 198990 the Regional Institute for Protection of Monuments performed protective researches (Јовановић and Цуњак, 1994, 107), as part of the site was endangered by the construction of a defensive embankment and canal. In 2004, the National Museum in Požarevac carried out minor archaeological researches, after which it was decided that extensive researches should be carried out due to the importance of the site. The National Museum in Požarevac conducted archaeological researches within the project The Town of Margum ${ }^{1}$ between April and November 2011. The research was conducted in collaboration with experts from the Institute of Archaeology. ${ }^{2}$

\footnotetext{
${ }^{1}$ Project The Town of Margum was conducted as a part of Cross Border Cooperation (CBC) with the Republic of Romania. The partner of the National Museum in Požarevac on this project, from the Romanian side, was the Museum of Banat from Timisoara.

${ }^{2}$ The excavations of the Margum/Morava in 2011 were headed by Perica Špehar and Ivan Bugarski from the Institute of Archaeology and Teodora Branković from the National Museum in Požarevac. The scientific supervisor was Vujadin Ivanišević from the Institute of Archaeology.
} 


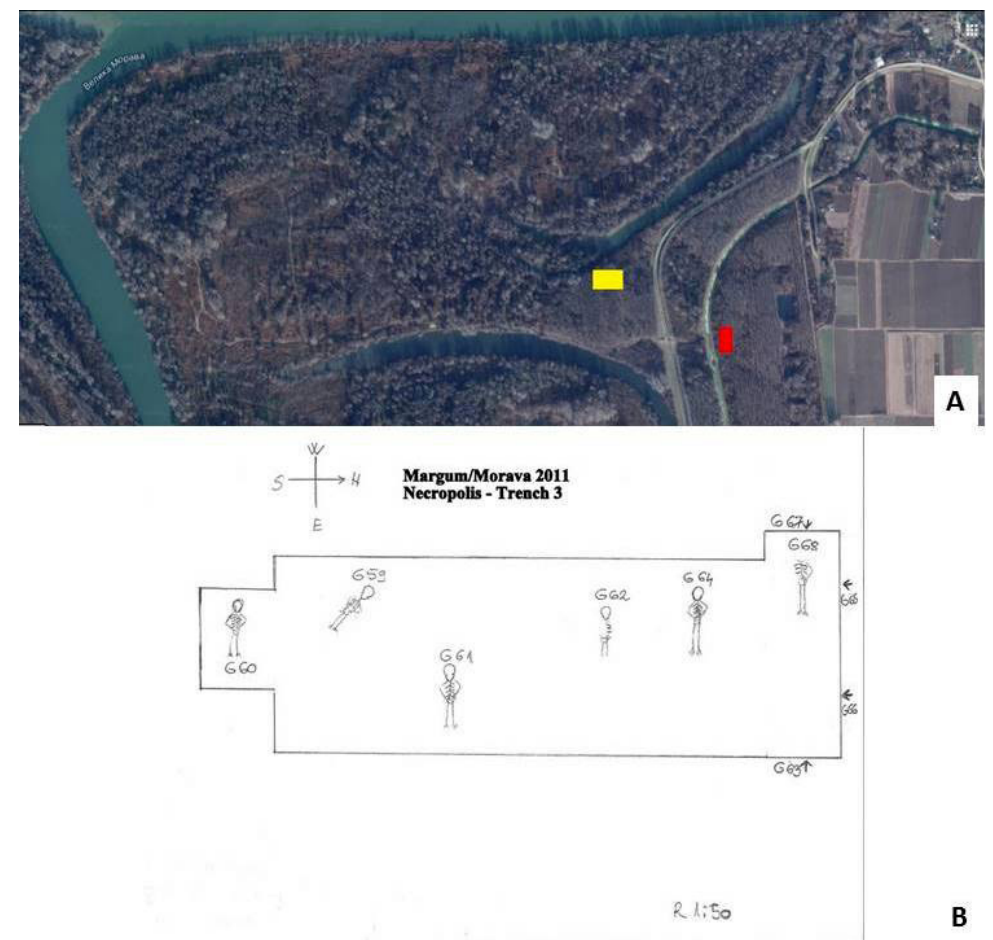

Fig. 1. A) Position of the site of Margum/Morava, as well as the zone excavated in 2011. The red rectangle represents the area of Velike Terme, and the yellow one the area of the Necropolis. B) Zone of the Necropolis, a sketch of the working situation with recorded orientation of the deceased

Сл. 1. А) Положај локалитета Маргум/Морава, као и зоне ископане 2011. Црвени правоугаоник представља зону Великих Терми, а жути зону некрополе. Б) Зона некрополе, радна ситуациона скица са забележеном оријентацијом покојника

The most extensive excavations were carried out at the site of Velike Terme ("Large Thermae"), where Trench 1 (dimensions: 20x10 m) was opened. The trench was placed at the highest point of the preserved part of the site of Margum/Morava, which was the least exposed to flooding by the Velika Morava (Иванишевић and Бугарски 2012, 249-250). In that area, two major habitation strata were observed, from the $11^{\text {th }}$ and the $12^{\text {th }}$ century. Layers dating from the second half of the $4^{\text {th }}$ century or the first half of the $5^{\text {th }}$ century were found below the medieval layers.

During the archaeological excavations at Margum/Morava in 2011, 17 graves were excavated. Ten graves were registered on the site of the Necropolis and seven graves in the area of Velike Terme (Fig. 1). However, out of seven graves from Velike Terme, only three graves contained skeletal remains, while 


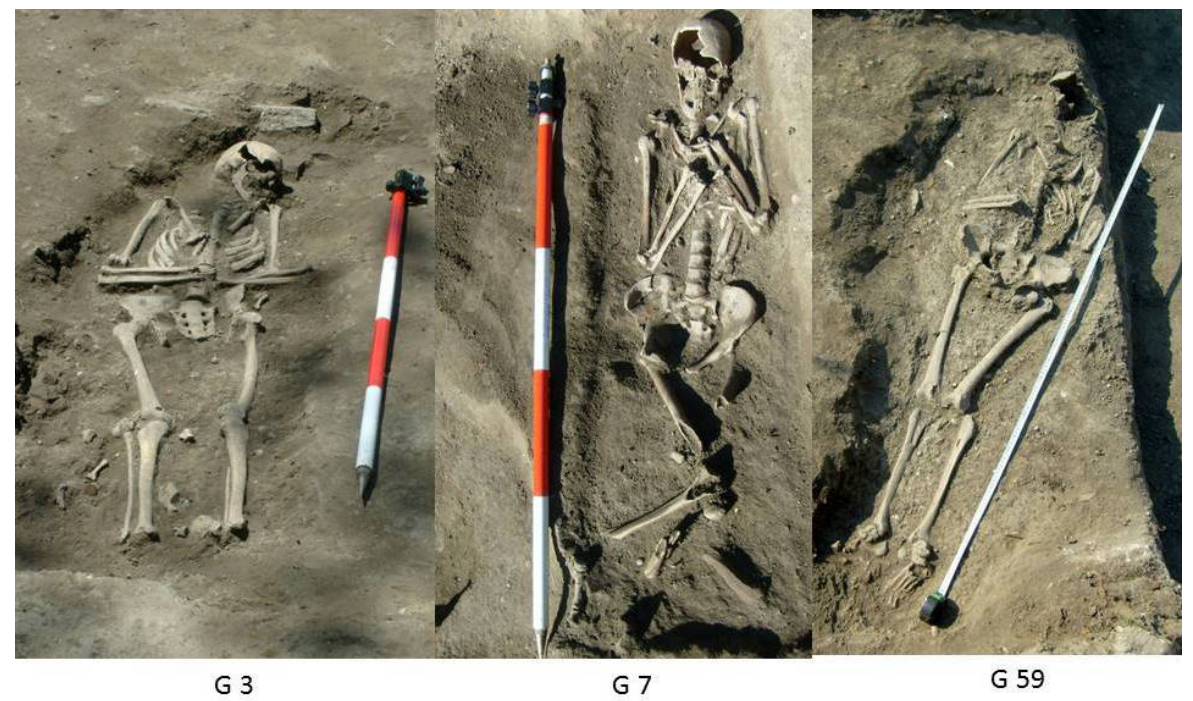

Fig. 2. Examples of burials at the site of Margum/Morava - graves excavated in 2011 were mostly oriented along the East-West axis, buried in gravel and clay soil, mostly without grave architecture and grave goods. They were laid on their back in a stretched position, with their arms usually on their pelvis

Сл. 2. Примери сахрањивања на локалитету Маргум/Морава - гробови ископани током 2011. године били су углавном западно-источно оријентисани са малим одступањима, слободно су покопани у шљунковитом и глиненом земљишту, положени на леђа у испруженом положају, с рукама углавном прекрштеним на карлици, а гробни прилози су били ретки

others were devastated. Due to the lack of grave goods, it is difficult to establish precise dating for them, especially for the graves from the area of the Necropolis.

In this paper, we will present the results of the analysis of individuals from graves in anatomical position only, eight in total (Fig. 2).

\section{Excavations in the area of Velike Terme}

Skeletal remains were found at several locations in the area of Trench 1. Only graves G3 and G7 were found in their primary position. In other cases, the remains probably originated from devastated graves. The graves found in the area of Velike Terme, in 2011, could belong to the medieval necropolis that was excavated in $2004^{3}$. The space between these two trenches has not been explored. However, based on the situation on the terrain, we can assume that some graves could be located in the unexplored area as well.

\footnotetext{
${ }^{3}$ The trench opened in 2004 is located about $100 \mathrm{~m}$ to the north-west from the trench from 2011. The excavation supervisors in 2004 were Dragan Jacnović and Dragana Spasić Đurić.
} 
Two main housing horizons have been observed in the area of Velike Terme, in the $11^{\text {th }}$ and the $12^{\text {th }}$ century horizon. Excavated graves could also be included in these horizons. Since Grave 3 was found at a depth of $0.5 \mathrm{~m}$, we can determine it into the horizon of the $12^{\text {th }}$ century, while Grave 7 could be determined into the horizon of the $11^{\text {th }}$ century. Grave 3 represents the most recent trace of use of this space in the Middle Ages (Bikić et al. 2012, 102). The dating is certainly made difficult by the lack of grave goods, but based on indirect findings, primarily fragments of pottery originating from waste pits, we can classify them in these two horizons of housing and burial.

From the horizon of the $11^{\text {th }}$ century comes a green-glazed vessel with a double beak and handles in the shape of animal heads, found in one of the waste pits, dated by the coins of Basil II, as well as a large number of fragments of glass bracelets with geometric ornaments in red and yellow. The most significant finds from the horizon of the $12^{\text {th }}$ century are: bronze sheet with a representation of a griffin, gilded bronze application with a decoration in the form of a carving, ending with a motif of a lily in the corners, two stone moulds for making pendants, bone skate, lead seal and others.

\section{Excavations of the Necropolis - Margum/Morava 2011}

The excavations performed from 1989-90 (Jovanović and Cunjak 1994) brought to light graves belonging to different burial horizons. The oldest horizon is represented by tombs of the Dubovačko-žurobrdska culture, and the most recent horizon is represented by graves dated into the period from the $9^{\text {th }}$ to the $11^{\text {th }} / 12^{\text {th }}$ century (Jovanović and Cunjak 1994, 107-122). Burials from the Antiquity and Late Antiquity horizons can be divided into several stages, from the $1^{\text {st }}$ to the beginning of the $5^{\text {th }}$ century. Graves from the Migration Period, firstly attributed to Gepids (Jovanović and Cunjak 1994, 120-122) and later to Heruli (Bugarski and Ivanišević 2013, 476) were also found within the Necropolis. Graves without architecture and grave goods are difficult to date precisely, so the authors dated them into the period from the $9^{\text {th }}$ to the $11^{\text {th }} / 12^{\text {th }}$ century, but with the assumption that they could have also belonged to the Late Antiquity period (Jovanović and Cunjak 1994, 119-120).

During the researches in 2011, 10 graves were excavated in this area. Six graves were investigated in detail, while the remains from 4 graves, which were collected during the mechanization operation, were only recorded but not fully excavated. Trench 3 at the Necropolis was located near the area excavated in 1989-90. The trench, originally $10 \times 4 \mathrm{~m}$ in size, was extended for $1.5 \mathrm{~m}$ to the south and 6.0 $\mathrm{m}$ to the north, located approximately $10 \mathrm{~m}$ from memoria. The graves excavated at 
the necropolis, during 2011, were marked with numerus currens continuously in relation to the numbers of graves previously explored at the site, from 59 to 68. Individuals were found in the supine position, with their arms crossed on their pelvises. One grave was excavated in the southern extension, and two in the northern one.

More precise dating of the graves excavated in 2011 was made difficult by the fact that they were without or with very few grave goods. During the excavations, those graves were dated into the Late Antique period (Bikić et al 2012, 101; Иванишевић and Бугарски 2012, 242), while previous researchers of this necropolis dated graves with similar characteristics into the most recent burial horizon in that necropolis, i.e. the period from the $9^{\text {th }}$ to the $11^{\text {th }} / 12^{\text {th }}$ century (Jovanović and Cunjak, 1994, 120-121). Essential traits of graves excavated in 1989/90 are orientation along the East-West axis, outstretched position of the skeleton with arms crossed on the chest, burials mostly without architecture, with rare confirmations of a wooden coffin and without or with very few grave goods. The graves excavated in 2011 were mostly oriented along the East-West axis, with small deviations, they were freely buried in gravel and clay soil, they were laid on their back in a stretched position, with their arms mostly crossed on their pelvis, and grave goods were rare. The following items were found in graves: Grave 61 (bronze ring and 1 Roman coin), Grave 64 (1 Roman coin) and Grave 68 (iron knife, a fragment of a bronze sheet, 2 Roman coins and fragments of medieval pottery). In two graves (61 and 64), iron wedges were found, which may indicate the existence of a burial structure. The typology of the bronze ring from Grave 61, in which a female individual was buried, could help us date that individual into the Medieval period. It was a banded ring (C 31/2011, Grave 61, Fig. 3), made of a bronze sheet with a flat, rectangular head. The hoop expands towards the shoulder and turns into a slightly raised head, rectangular in shape. There are traces of an unrecognizable engraved ornament on the head. The diameter of the ring is 2.1 $\mathrm{cm}$, and the dimensions of the head are $1.4 \times 1.1 \mathrm{~cm}$. Rings with similar traits are classified into the period of the $10^{\text {th }}-13^{\text {th }}$ century (Шпехар 2007, 373; БајаловићХаџи Пешић 1984, 43). Therefore, based on the previously described properties of the burials, as well as the presence of the banded ring, it was concluded that those graves can be dated into the Medieval period. Nevertheless, in the same grave with the ring (G 61), a Roman coin was found, suggesting different dating. However, we should take into account that Roman coins $\left(2^{\text {nd }}-4^{\text {th }}\right.$ century) have been found before in medieval graves $\left(10^{\text {th }}-15^{\text {th }}\right.$ century) of female individuals (Ćirić 2016: 731), in secondary use. It is also possible that older money in multilayered sites, such as Margum/Morava, may also come from the filling of a grave, i.e. layers of soil from the Roman period that were disturbed by medieval burials. 

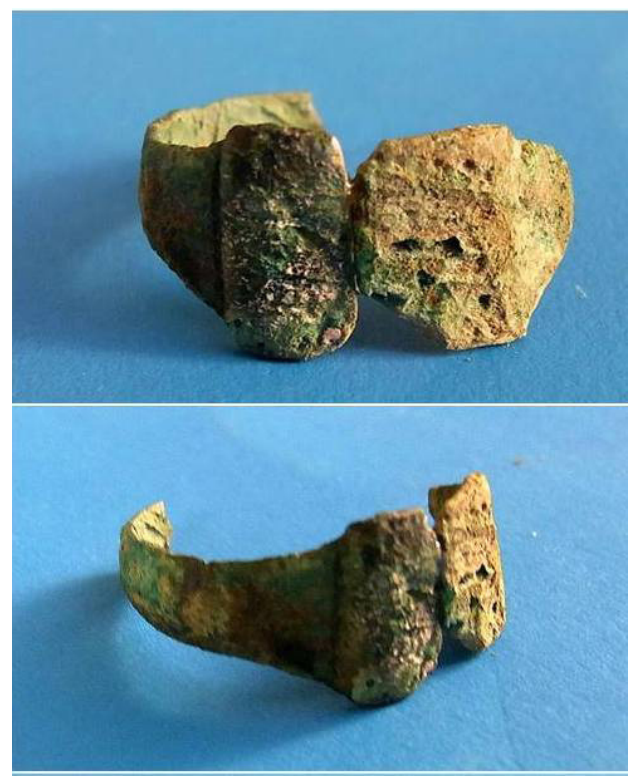

Fig. 3. A banded ring made of a bronze sheet with a flat, rectangular head and unrecognizable engraved decoration. The diameter of the ring is $2.1 \mathrm{~cm}$, and the dimensions of the head are $1.4 \times 1.1 \mathrm{~cm}$. Rings with similar traits are classified as belonging to the period of the 10th-13th century (Шпехар 2007, 373; БајаловићХаџи Пешић 1984, 43)

Сл. 3. Тракасти прстен израђен је од бронзаног лима са плочастом, правоугаоном главом и траговима непрепознатљивог урезаног орнамента. Пречник прстена је 2,1, димензије главе 1,4 x 1,1 цм. Тракасто прстење сличних карактристика сврстава се у хоризонт 10-13. века (Шпехар 2007, 373; Бајаловић-Хаџи Пешић 1984, 43)

\section{Material and methods}

The preservation index (PI) was used for the calculation of the degree of skeletal preservation, as proposed by Walker and colleagues (Walker et al. 1988, 387).

To determine the sex of an adult individual, the methods of Walker (2005, 388-390), Buikstra and Ubelaker (1994, 19-21), and Buikstra and Meilke (1985, 422) were used.

In the present study, the estimation of the sex of non-adult individuals was not performed, since secondary sexual characteristics hadn't developed yet (Ferembach et al. 1980, 523), and it has been observed that morphological methods are unreliable due to low inter-observer agreement (Bruzek 2002, 160).

For the age estimation, methods based on changes on the pubic symphyseal surface (Brooks and Suchey 1990, 235), the auricular surface of the ilium (Lovejoy et al. 1985, 19) and methods based on tooth-wear (Brothwell 1981, 
71-72) were used in this study. Methods based on epiphysis fusion and tooth eruption were used for the age estimation of non-adults. We relied on Scheuer and Black's (2000) methods for the timing of the fusion of the epiphysis, while the method of AlQahtani $(2012,149)$ was used for teeth eruption.

For entheseal changes, a modified method of Mariotti and colleagues (Mariotti et al. 2007), based on the scoring for twenty-three entheses of the postcranial skeleton of upper and lower limbs, was used. Other markers of occupational stress that were considered as indices of work-related activities are Schmorl's nodes, disc herniation, Charles' facet and squatting facets.

Once we had established the age at death and sex of an individual, we proceeded to take osteometric measurements. To calculate the stature, we used formulas of Pearson (1899).

Pathological conditions, trauma, or taphonomic changes observed were recorded and photographed. Descriptive methods were used for the analysis of pathological changes (Campillo 2001). The remains were examined macroscopically: visual inspection with the naked eye, under natural light; and microscopically: with a 10X magnifying glass. Regarding oral pathologies, they were collected from individual dental charts, where we used the codes proposed by the International Dental Federation.

\section{Results}

\section{Velike Terme - Trench 1}

$\underline{\text { G3 }}$

The grave was found at a depth of about $0.5 \mathrm{~m}$ in a layer in which large fragments of mostly medieval pottery were found. The individual was found in the prone position, oriented along the East-West axis, with legs outstretched, head turned to the left, and arms crossed at the abdomen. The burial pit could not be defined clearly. There were no burial goods in the tomb, but after lifting the individual, a corroded iron object of undefined use and a glass object of undefined shape were observed below. These findings probably originated from the layer in which the deceased was buried.

The remains found were that of a male individual, well-preserved, with the preservation index $(\mathrm{PI})=95.45 \%$, about $40-50$ years old. The stature of that individual was estimated at $168.9 \mathrm{~cm}$. It was a robust individual, with extremely pronounced muscle entheseal development (2.5-3, on the scale of 0-3). Other markers of occupational stress, such as Schmorl's nodes and squatting facets, were also noted. Many dental pathologies were observed, such as antemortem tooth loss (AMTL), caries, abscess, periodontitis and calculus (Fig. 4). Although 


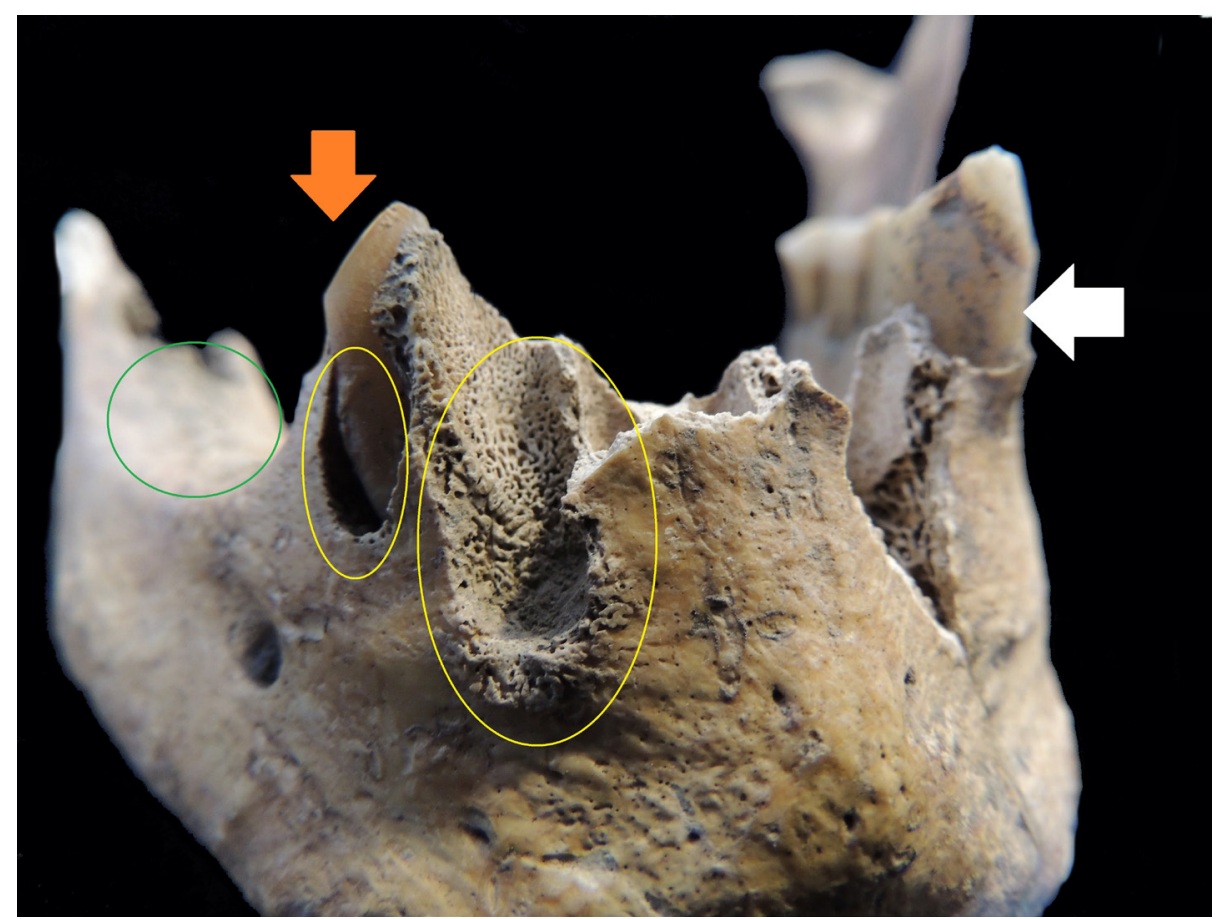

Fig. 4. Individual G3 had many dental pathologies, such as antemortem tooth loss (green circle), caries, abscesses (yellow circles), periodontitis (white arrow) and calculus. It can also be observed that teeth were very worn-out (orange arrow)

Сл. 4. Индивидуа G3 је имала много зубних патологија, попут заживотног губитка зуба (зелени круг), каријеса, апсцеса (жути кругови), периодонтитиса

(бела стрелица) и каменца. Такође се може приметити да су зуби били врло истрошени (наранџаста стрелица)

we do not have complete data for the dental pathology for this individual (more than half of the maxilla was not preserved, many teeth were lost postmortem), it could still be concluded that his dental health was very poor, with large antemortem tooth loss ( 5 teeth of 15 preserved alveoli), numerous instances of caries (4 teeth in the alveoli and 2 fallen teeth had caries, in some cases to the very root), as well as 3 cases of an abscess.

As for other pathologies, moderately pronounced osteoarthritis (OA) was found on all joints in the body, equally distributed. An exception was OA observed on vertebrae, especially lumbar ones, where remarkable prominent degenerative changes occurred, followed by osteophytes (bone growths formed at the ends of degenerative cartilage).

The presence of coxa vara, a deformity of the femoral neck or hip area, in which the angle between the femoral neck and the femur shaft is reduced, was ob- 


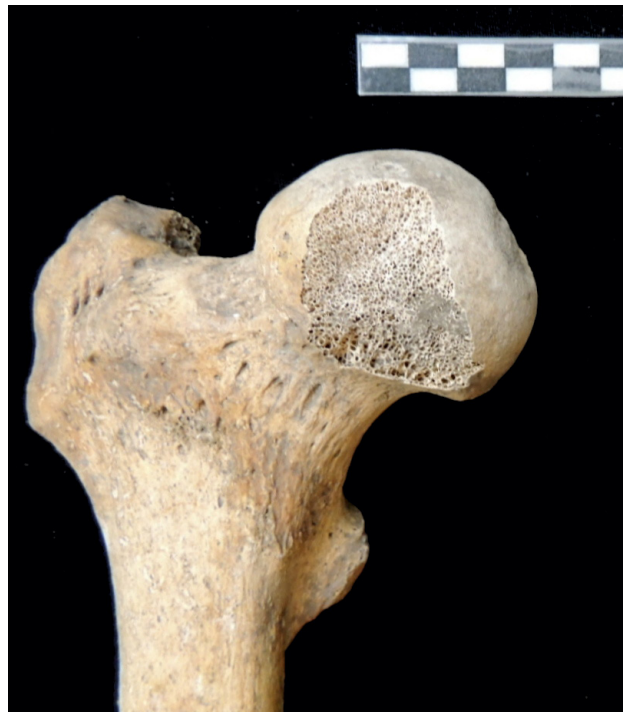

Fig. 5. Coxa vara, deformity of the femoral neck or hip area, in which the angle between the femoral neck and the femur shaft is reduced. The normal value is $120^{\circ}-130^{\circ}$ in an adult, while the angle in G3 is $115^{\circ}$

Сл. 5. Соха vara, деформитет врата фемура или кука, у коме се смањује угао између врата и тела фемура. Нормална вредност код одрасле особе је 120-130, док угао код G3 износи $115^{\circ}$

served in that individual (Fig. 5). Coxa vara is characterised by a decrease in the angle of inclination of the femoral neck, whose normal value at birth is $140^{\circ}-150^{\circ}$ and $120^{\circ}-130^{\circ}$ in an adult (Shapiro 2001,376 ). If this value is below $120^{\circ}$, like in this individual $-115^{\circ}$, the person is considered to have had coxa vara (Ibid.).

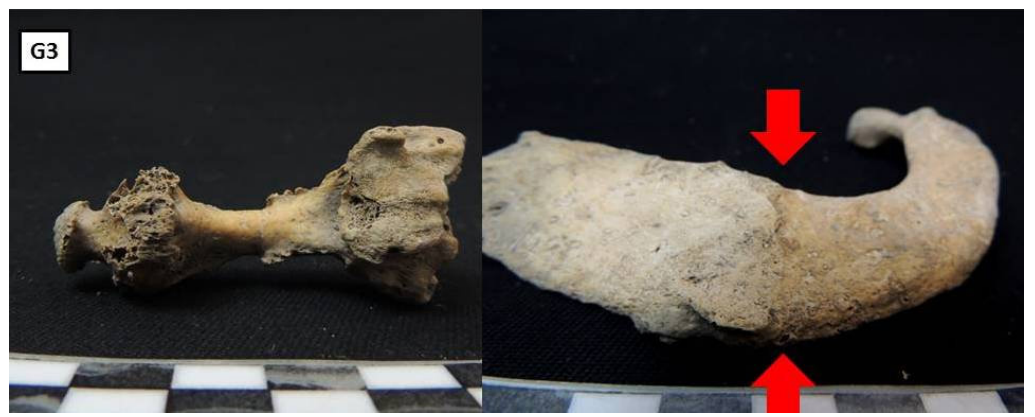

Fig. 6. Two antemortem fractures detected in individual G3 - of the first left rib and of the metatarsal of the right foot

Сл. 6. Два заживотна прелома уочена на индивидуи G3 - на првом левом ребру и на метатарсалу десног стопала

Two antemortem fractures were detected in the individual - on the first left rib and the second metatarsal of the right foot (Fig. 6). It was not possible to say precisely how much time passed since the injury occurred, or whether they happened at the same time. The fracture on the metatarsal did not heal well, and there was a fusion between it and the proximal phalange, followed with posttraumatic osteoarthritis. 


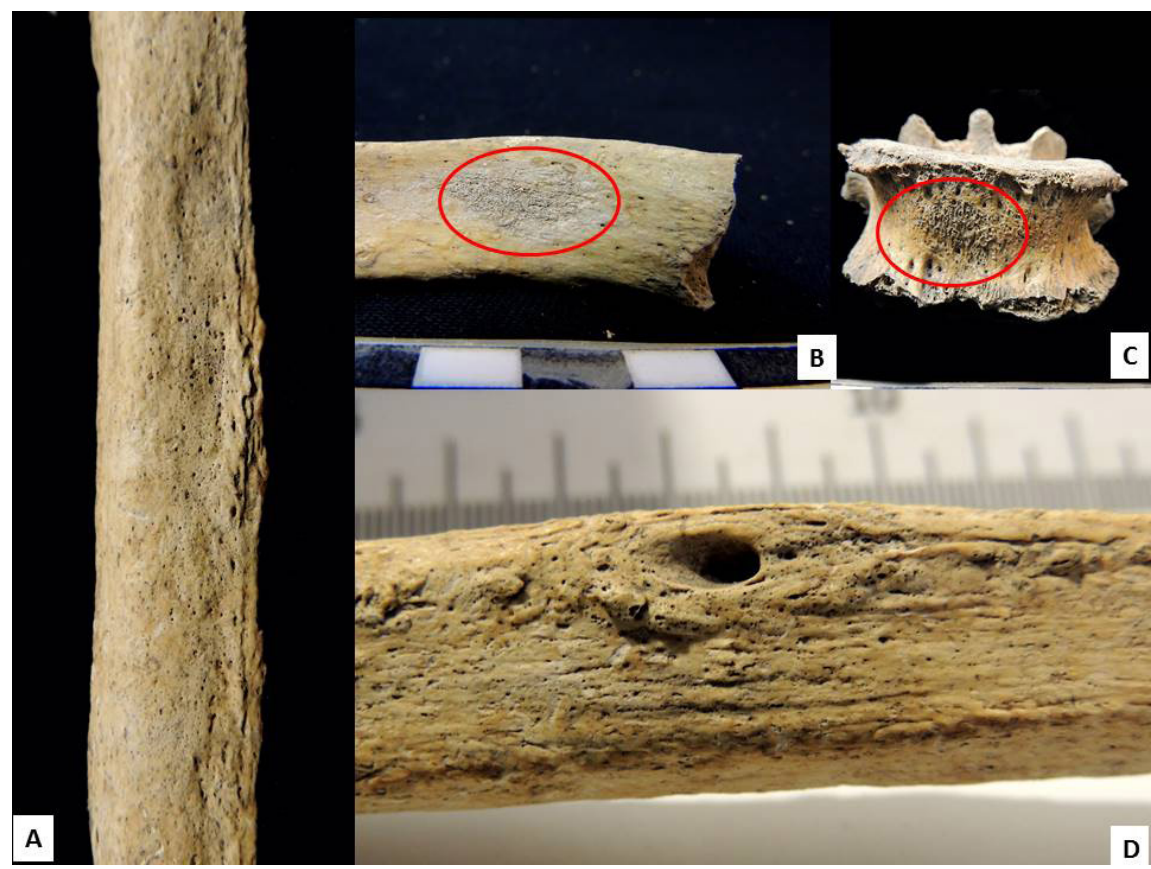

Fig. 6. Bone changes such as abnormal porosity (A), observed in almost all parts of the skeleton, presence of lesions on the vertebrae (C), lower legs (D), porosity and formation of a new bone layer on the inner part of the ribs (B), are, most likely, signs of pulmonary tuberculosis

Сл. 6. Промене на костима, као што су абнормална порозност (А), примећене у готово свим деловима скелета, присуство лезија на вертебрама (C) и потколеницама (D), порозност и стварање новог слоја кости са унутрашње стране ребара (B) највероватније су знакови плућне туберкулозе

Abnormal porosity was observed in almost all parts of the skeleton. The distribution and morphology of those pathological changes, as well as the presence of lesions on the vertebrae, lower legs, porosity and formation of a new layer of bone on the inside of the ribs, were most likely the consequences of tuberculosis, which will be considered in more details in the discussion section (Fig. 7).

$\underline{G 7}$

Grave 7 was located in the zone where two medieval burials were found, one of which represents the negative of the wall that follows to the northwest and breaks at a right angle towards the southern profile. From the remaining material, observed in the profile itself, it can be concluded that it was a dry stone and that the corner of the building was captured in the negative. Medieval pottery was collected during the cleaning. 
The grave belonged to an adult individual, with southeast-northwest orientation. The individual was found in the prone position, with legs bent at the knees and arms crossed at the chest. Fragments of medieval pottery, as well as two coins dating from the $4^{\mathrm{h}}$ century, were found in the sediment used to fill the tomb.

The individual was female, approximately 50-60 years old. The state of preservation was medium, with $\mathrm{PI}=68.18 \%$. The stature of this individual was $160.9 \mathrm{~cm}$. Muscle insertions were poorly, or medium prominent (grade 1 or 2), except for the left scapula, where the prominence was very strong (grade 3), but overall, it was not an overtly robust individual.

Schmorl's nodes were observed on most thoracic vertebrae. Very pronounced osteoarthrosis on the vertebrae was also observed, as well as spinal asymmetry.

Dental hygiene was really poor. Calculus deposits were found on most teeth, as well as caries, abscess, and antemortem tooth loss. Out of the 30 alveoli that were preserved, two showed AMTL, while out of 22 retained teeth 7 had caries, often to the very root. Also, one abscess was observed, and almost all teeth had calculus deposits and periodontitis.

Although the shins of the left leg were quite fragmented, a highly developed infection in the preserved parts of the left tibia and fibula was observed (Fig. 8). Because the right leg and other parts of the body were not affected, it was most likely that infection occurred due to a fracture or other type of injury.

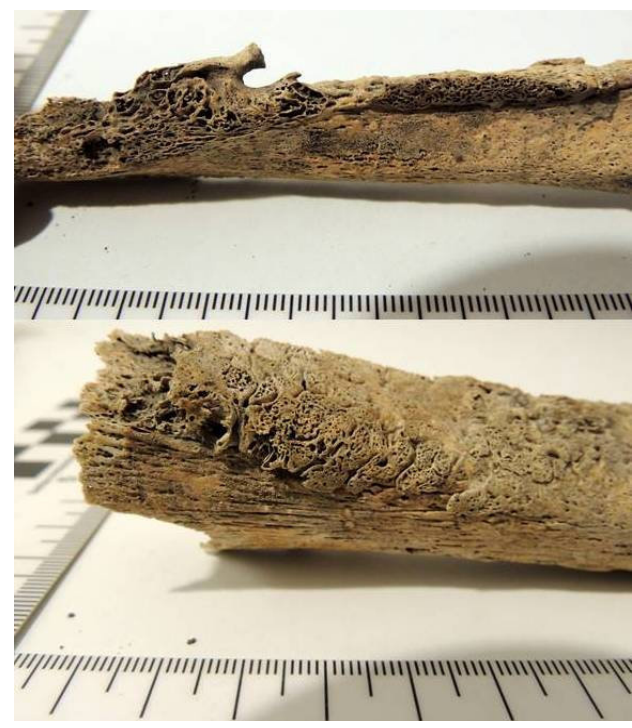

Fig. 8. Severe post-traumatic infection in the preserved parts of the left tibia and fibula in individual G7

Сл. 8. Тешка посттрауматска инфекција уочена на сачуваним фрагментима леве тибије и фибуле код индивидуе G7

\section{Necropolis - Trench 3}

\section{$\underline{G 59}$}

The grave belonged to an adult individual, buried directly in the soil. No traces of a grave structure were discovered. The orientation of the skeleton was southeast-northwest, with the skull at the northwest. No grave goods were found. 


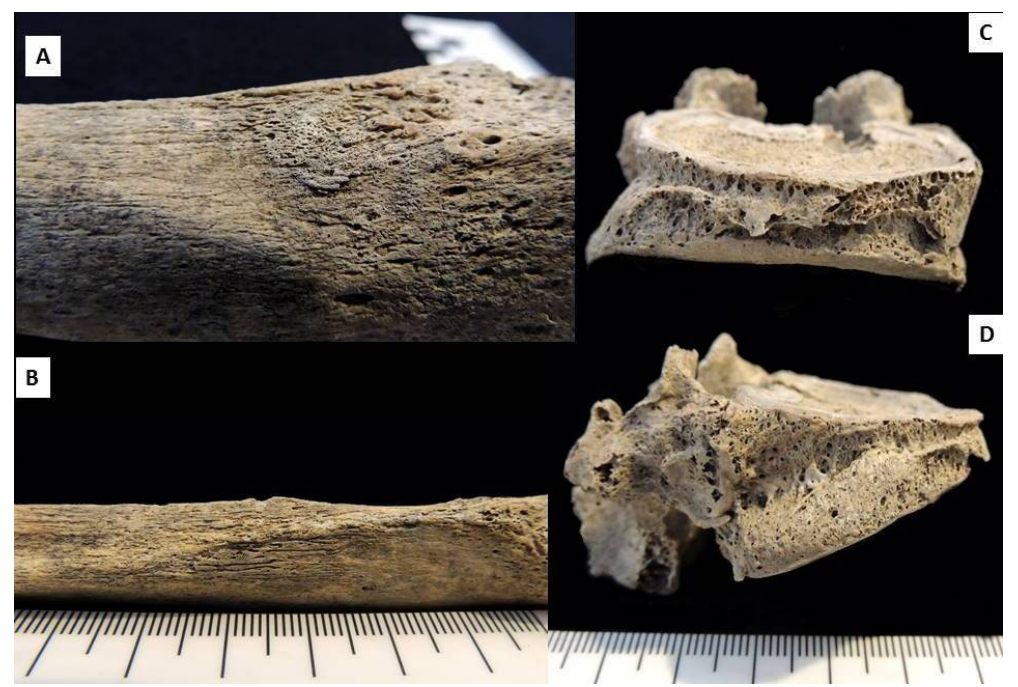

Fig. 9. Abnormal porosity, the formations of layers of a new bone (A, B) and numerous lesions were noticed on the entire skeleton of individual G57, as well as a complete collapse of the vertebrae $(\mathrm{C}, \mathrm{D})$. These are most likely signs of tuberculosis of the spine (Pott disease)

Сл. 9. Примећена је абнормална порозност, стварање слојева нове кости $(\mathrm{A}, \mathrm{B})$ и бројне лезије на читавом скелету индивидуе G57, као и потпуни колапс пршљенова (C, D). Ово су највероватније знакови туберкулозе кичме (Потова болест)

It was estimated that the individual was female, about 50-60 years old. Skeletal remains were well preserved, with the preservation index of $81.8 \%$. The stature of this individual was $153.57 \mathrm{~cm}$. Muscle insertions were poorly, or medium prominent (grade 1 or 2), with most prominent insertions on the Achilles tendon. Out of other markers of occupational stress, we noticed squatting and Charles' facets.

Dental hygiene was extremely poor, and calculus deposits were present on most teeth. Caries was also observed on eight teeth (often in multiple places on the same tooth and in some cases it reached the root), as well as periodontitis and abscess. It was observed that tooth abrasion was very uneven, which can be a result of antemortem tooth loss, causing a lack of occlusion (contact between the teeth) and, therefore, less dental abrasion.

Pathological changes in the form of abnormal porosity and the formation of layers of new bone were observed throughout the skeleton. Besides, numerous lesions on the body were noticeable. Due to the distribution and appearance of porosity, changes in the ribs and vertebrae, as well as the complete collapse of vertebrae (Pott disease), it was concluded that tuberculosis was the most probable diagnosis (Fig. 9). 
Medium pronounced osteoarthrosis was also noted on the entire skeleton, which was somewhat more intense on the right side of the body.

$\underline{G 60}$

This grave contained a skeleton in the supine position, with the right hand resting on the abdominal area, while the left hand was bent at the elbow upwards. The tomb was oriented along the East-West axis. No grave goods were found.

It was a male individual, about 18-20 years old. The preservation level was very good, $\mathrm{PI}=95.4 \%$. Since this was an individual whose development was not completed, we did not determine his height. For the same reason, we did not estimate the degree of prominence of muscle insertions. Since muscles develop until the age of 25 (Kuczmarski et al. 2000), there is an agreement in physical anthropology that for those individuals whose development is still incomplete, entheseal changes should not be analysed.

Although the individual was very young, he had caries lesions on three teeth and calculus deposits on a large number of teeth. At least two lines of hypoplasia were also observed, which tells us that that person went through at least two episodes of childhood physiological stress.

Regarding other pathologies, OA was observed at the base of the skull, the distal end of the left and right humerus, and on the feet. Although it was a very mild change, the appearance of OA can be considered quite unusual, given the age of the individual, as that change usually does not occur until the age of 40 (Anderson and Loeser 2010, 17).

\section{$\underline{G 61}$}

The grave marked G61 was located at a relative depth of $0.35 \mathrm{~m}$. The orientation of the grave was East-West. The skeleton was buried directly into the ground, in the supine position, with arms crossed at the pelvis. It was partly damaged by mechanisation. The already mentioned banded ring, made of a bronze sheet, was found on the individual's hand and a Roman coin was found in the grave.

The individual buried in the grave was female, about 18-20 years old. The preservation level was medium, with $\mathrm{PI}=63.6 \%$. For the previously explained reasons, we did not estimate the stature nor perform an analysis of entheseal changes.

All 5 teeth preserved in the alveoli had caries, some of them with two on the same tooth, and it was observed on one of the teeth found outside the alveoli. Lines of hypoplasia on incisors and canines were also noted, as well as deposits of calculus on several teeth. 
Abnormal porosity was observed on the skull, mandible and long bones, often accompanied by the formation of a new layer of bone. Cribra orbitalia was observed on the right orbit (the left one was not preserved). Since this individual was an adolescent, we based the age-determination on already mentioned methods - tooth eruption (AlQahtani 2012, 149) and the degree of epiphyseal fusion (Scheuer and Black 2000). According to the first method, it was determined that all teeth, including the third molar, had erupted, but that the root of the third molar was not completely closed. Therefore, it can be concluded that the individual was at least 18 years old (AlQahtani 2012, 149). In contrast, no epiphyseal fusion on the long bones was noticed. Bearing in mind that this was a female individual, whose epiphyses normally fuse earlier than those of male individuals, at that age, she should have been near the end of that process (Scheuer and Black 2000). That was a serious growth delay, which may be related to the pathology which will be discussed later.

On the phalanges of the right hand, a taphonomic colourisation (green stains) was observed due to the contact with the oxidised copper object.

$\underline{G 62}$

In this grave, poorly preserved skeletal remains of a non-adult individual were found. Only fragments of the skull and fragments of the lower extremities were preserved.

The individual was approximately 1.5-2 years old, based on the length of long bones (teeth were not preserved). The preservation index was $13.6 \%$, which limited the investigation possibilities. For the reasons stated previously, we did not determine the gender of this non-adult individual.

No pathological changes were observed in this individual.

\section{$\underline{G 64}$}

The individual found in this tomb was in the supine position, arms folded on the pelvis, with the East-West orientation. The skeleton is well preserved, but the skull was damaged when the layers of soil above it were removed. Two wedges originating from the burial ground were found in the area of the upper arm or the shin. In the filling of the tomb, approximately in the chest area, a Roman coin was found. The coin was heavily patinated, $2 \mathrm{~cm}$ in diameter.

The individual was male, about $40-50$ years old. The preservation level was good, with $\mathrm{PI}=77.27 \%$. The stature was estimated to be $169.29 \mathrm{~cm}$.

Muscle attachments were quite uneven, that is, far more pronounced on the right side, both at the upper and lower extremities. That suggested that the 
individual, besides being right-handed, also frequently performed some work involving his right leg.

Very pronounced Schmorl's nodes were observed on the lower thoracic vertebrae and one lumbar vertebra. In addition, discuss hernias were observed.

Large calculus deposits were observed on most teeth, one abscess, several AMTL, periodontitis and minor caries on the lower premolar. The agenesis of all four wisdom teeth (third molars) was also observed, and the maxilla showed the existence of an alveolus containing the third molar but rather irregularly placed in relation to the other teeth, which probably prevented their emergence.

As for other pathologies, only OA was observed, slightly pronounced on several thoracic vertebrae, on the bones of the feet, the occipital condyle, and the right wrist.

Taphonomic colouration caused by contact with the oxidised bronze object was observed on one of the left ribs.

\section{$\underline{G 68}$}

The individual buried in this tomb was in the supine position, with the left hand on the pelvis and the East-West orientation. The skeletal remains suffered damage, probably due to the collapse of a nearby wall or a similar object. It could be seen in the photograph from the field that the skull, cervical vertebrae, shoulder girdle and the entire right arm (except the hand) were missing. Two bronze coins were found in the grave soil, both in the foot area. A smaller bronze sheet was found in the pelvic area, while an iron knife was found on the right side, along with some fragmented pottery. The coins were heavily patinated, $2.1 \mathrm{~cm}$ and $1.7 \mathrm{~cm}$ in diameter.

The individual was female, about 40-50 years old. The rest of the skeletal material that was not missing was well preserved, with $\mathrm{PI}=54.5 \%$. Her stature was very short, only $147.92 \mathrm{~cm}$, according to Pearson (1989).

Although a relatively small and slender individual, the muscular attachments on the left arm (the right one was not preserved) were moderately prominent (grade 2 on the scale of 0 to 3 ). At the same time, at the lower extremities, these values ranged from weak to medium, leading us to the conclusion that, in her daily activities, this person used arms more than legs. Also, Schmorl's node was observed on one of the lumbar vertebrae. Other occupation markers included squatting facets on the tibias and Charles' facets on femurs.

There was also pronounced OA on the lumbar spinal vertebrae, while less pronounced OA was observed on the left elbow, left hip, knees and feet.

Only one tooth was preserved, the incisor, with calculus deposits. 


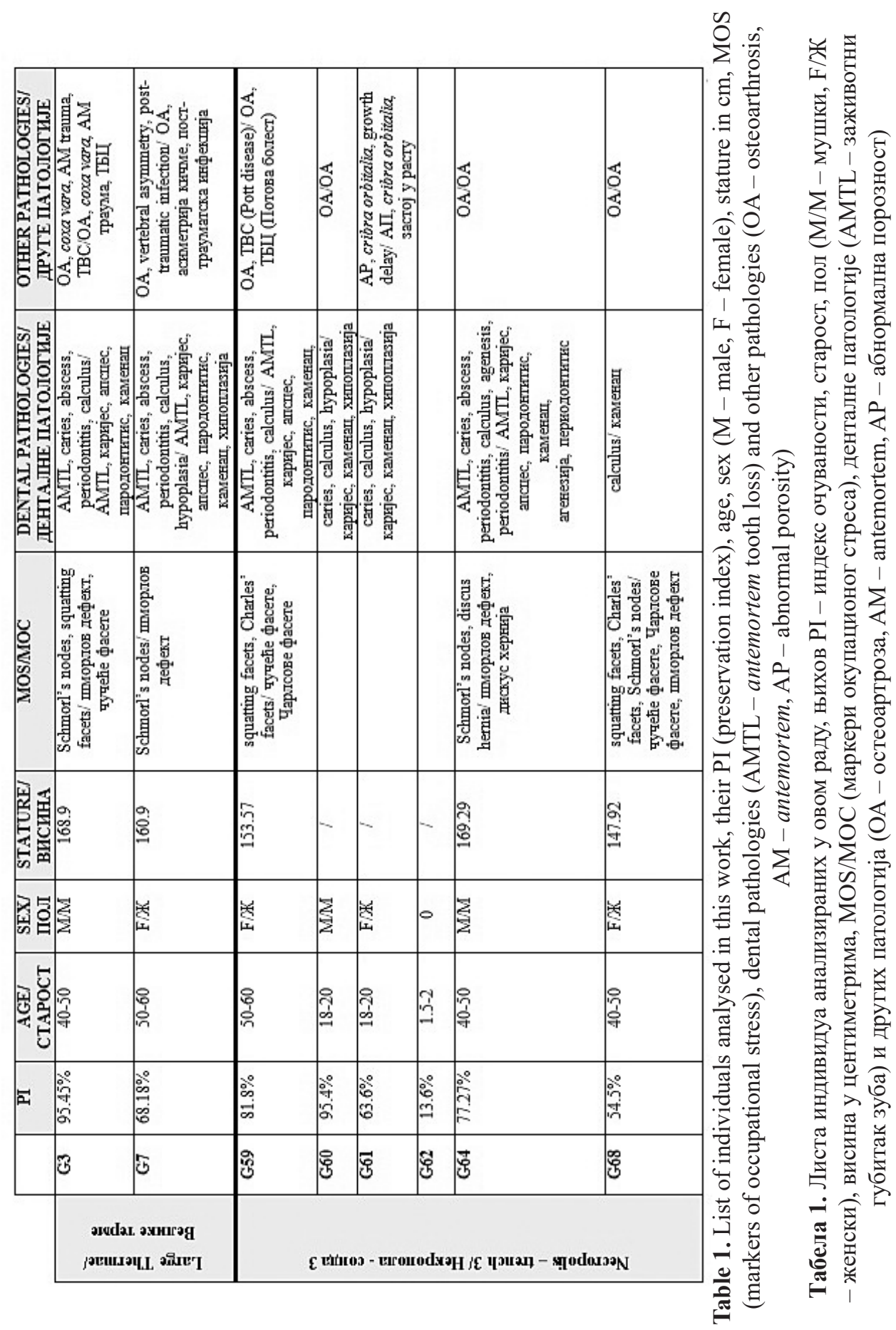




\section{Discussion}

Schmorl's nodes are herniations of a part of the nucleus pulposus out of the fibrosis wall of the intervertebral disk when the herniation does not cross the annulus fibrosus (Capasso et al. 1999, 38). Most of the cases can be noted on the lumbar vertebrae. While some authors interpret this phenomenon as a result of physical effort and carrying heavy loads (Capasso et al. 1999, 38; Lovell 2008, 355; Waldron 2009, 45), others think that its aetiology may be idiopathic (Roberts and Manchester 1995). However, it is noted that this phenomenon is very common in populations that are known, from historical sources, for performing regularly very exhausting physical work (Phillips 2003, 97; Herrerín et al. 2018, 138) and among sportspersons dedicated to weight lifting (Aggrawal et al. 1979, 60). Although it is possible that other factors, including hereditary (Williams 2007, 859), influence the incidence of nodules, physical activity also plays a role. In this study, Schmorl's nodes were noted in 4 adult individuals.

Disc herniation is a more severe condition than Schmorl's nodes when parts of the herniated nucleus pulposus cross the annulus fibrosus. Clinically, the most serious consequences occur when the nucleus pulposus slips into the spinal canal, producing pressure on the spinal cord or nerve roots, causing severe pain and other nervous disorders (Huether and McCance 2016, 388). It can be a consequence of ageing and general "wear and tear" (Benoist 2003, S88), but also of the repetitive mechanism of flexion-extension of the torso and carrying heavy loads (Baxarias and Herrerín 2008, 212). It was noted in one individual from this population.

Charles' facets are impressions located above the articular surface of the medial epicondyle of the femur. The facets occur due to the extension of the articular surface caused by the contact with the tibial condyle during hip flexion (Capasso 1999, 94).

Squatting facets are morphological changes in joints, observed on the anterior surface of the distal tibia and the neck of the talus, linked to hyperflexion of the joints during a squatting posture (Dlamini and Morris 2005, 375). In hyperdorsiflexion of the foot, such as in a squat, the anterior aspect of the distal tibia articulates with the superior surface of the talus, or the lateral aspect of the neck, in particular. Squatting was a common resting position for populations that had no availability of furniture, or that chose that position for cultural reasons. They were generally more frequent among women, probably because various household chores, such as cooking or washing laundry, were performed in a squatting position (Baxarias and Herrerín 2008, 216). In this population it was noted in three individuals - two females and one male. 
Dental health was very poor and all individuals that had teeth preserved had various dental diseases, such as AMTL, caries, abscess, periodontitis and calculus.

Dental enamel hypoplasia, noted in 3 individuals, is a defect in the enamel formation process that indicates the existence of a period of physiological stress experienced by the individual during the formation of the dental crown. This process can last from the prenatal period up to 12 months in deciduous teeth, from the birth to 7 years for permanent teeth (Hillson 2005, 174), and up 16.5 years for third molars (AlQahtani 2012, 146), which makes it a good indicator of non-specific stress in childhood.

One of the individuals with enamel hypoplasia (G61, young female) also had other signs of metabolic stress, namely, abnormal porosity (AP) and cribra orbitalia (CO). AP was observed on the skull, mandible, and long bones, often accompanied by the formation of a new layer of bone. On the right orbit (the left one was not preserved), $\mathrm{CO}$ was observed, which was associated with metabolic problems and malnutrition. The appearance and distribution of porosity indicated a major metabolic problem, most likely anaemia and/or scurvy, which could have caused a delay in the development of that individual.

Antemortem fractures were noted on two individuals from Velike Terme (fracture of the rib, the foot in G3 and the shin in G7). According to their type and location, both seemed to be caused by accidents. In both cases, the healing of the fracture was not appropriately done: in the case of G3, the fusion of metatarsal and phalange resulted in reducing the mobility of the foot, while in the case of G7, considering the severity of the infection, as well as the fact that it was still in the active phase at the time of death, it was most probably precisely this wound that led to the fatal outcome.

There were two possible cases of tuberculosis, although not of the same type. The individual G3 had abnormal porosity observed on almost all parts of the skeleton. The distribution and morphology of those pathological changes, as well as the presence of lesions on the vertebrae, lower legs, porosity and formation of a new layer of bone on the inside of the ribs, are characteristic for tuberculosis. A study based on the Coimbra Identified Osteological Collections (Matos and Santos 2006, 191) showed that new bone formation on long bones and ribs was significantly more common in individuals who died from TBC than in individuals who died from a nontuberculous cause. Although new bone formation in ribs could appear in some other pulmonary diseases, this bone lesion was present in $90.9 \%$ of individuals who died from pulmonary TBC, and only in $4.2 \%$ of individuals who did not die from TBC. 
In individual G59, pathological changes in the form of abnormal porosity and the formation of a layer of new bone are noticeable throughout the skeleton. In addition, numerous lesions on the body, together with changes on the ribs and vertebrae, as well as a very characteristic collapse of vertebrae known as Pott disease, could also be seen. Pott disease or tuberculous spondylitis, before the mid-twentieth century, typically resulted in dismal neurological, functional and cosmetic outcomes (Khoo et al. 2003, 130). The clinical presentation of spinal tuberculosis is variable and their manifestations depend upon the duration of illness, severity of the disease, site of the lesion (Ansari et al. 2013, 404). In less severe cases the patient typically experiences back pain; while the complicated tubercular spine disease involves deformity, instability, and neuro deficit (Viswanathan and Subramanian, 2019). Back pain in tuberculosis can be related to the active disease itself (secondary to inflammation), bone destruction and instability.

Tuberculosis is a contagious disease caused by Mycobacterium tuberculosis. The classic symptoms of an active TBC infection are chronic cough with bloody spit, fever, night sweats and weight loss. Although in the past, before the discovery and mass use of vaccines, tuberculosis was a widespread disease, findings of skeletal remains with these changes were relatively rare. The reason is that TBC would first attack the soft tissue and individuals would have died before skeletal modifications could take place (Wood et al. 1992). Therefore, findings of skeletal changes connected with TBC were only noticeable in people who lived with that disease for a long time, and therefore they present a valuable finding.

According to historical sources, tuberculosis in Serbia affected around 30 out of 10,000 people during the late $19^{\text {th }}$ and early $20^{\text {th }}$ century (Sretenovitch 1922,11 ). Other sources mention 225-464 per 100,000 deaths (Grmek, 1970) before antibiotics become frequently used. Important information about the frequency of tuberculosis comes from the "Health Book", printed in 1930 in the former Kingdom of Yugoslavia, where proverbs stating that the death rate from consumption ${ }^{5}$ is greater than all the evils in war and that "the highest taxes are paid in consumption", 6 were mentioned. Although we don't have data for Serbia before the $19^{\text {th }}$ century, it is a well-known fact that tuberculosis was the most deadly disease in Western Europe at the beginning of the industrial period; for ex-

\footnotetext{
4 "Čitanka o Zdravlju", originally printed by the School of Public Health "Andrija Štampar", School of Medicine, University of Zagreb, 1930. Reprinted in "Hrvatska književnost i zdravlje", Vol 4, No 13, 2008.

${ }^{5}$ The word "consumption" ("sušica" in Serbian and Croatian) first appeared in the $14^{\text {th }}$ century to describe any potentially fatal wasting disease that is "consuming" the body, but over time it came to apply more specifically to tuberculosis.

6 "Više sušica umori, nego što rat zla stvori”; "Najveći porezi plaćaju se u sušici".
} 
ample, one of every four deaths recorded in parish registries from England at the end of the $18^{\text {th }}$ century was attributed to this disease (Davis 2000, 42). Even if we take into account the fact that in the $18^{\text {th }}$ century Serbia was less populated than England, and therefore the possibility of infection was lower, we have reason enough to believe that tuberculosis was not uncommon at all. Notwithstanding, only a small number of cases has been recorded in the entire territory of today's Serbia. Djurić-Srejić and Roberts $(2001,316)$, analysing 1617 skeletons from the Late Medieval period, found only 4 probable cases, from Trgovište, and 3 possible cases from Vinča. Lovász et al. $(2010,87)$ were trying to apply two criteria on the $16^{\text {th }}-17^{\text {th }}$ century anthropological series from Sombor, focusing on the "classical/advanced stage skeletal TB alterations" and the "atypical/early-stage TB lesions". In the first category, they noted 2 probable and 32 possible cases, and in the second one out of 196 individuals. The main problem is that many other diseases share the same traits as the "atypical/early-stage TB lesions", thus making it hard to claim that it was TBC with certainty. A case of tuberculosis was documented at the necropolis from the Avar period in Bačka Topola (Farkas et al. 1976, 232). Miladinović Radmilović (2012, 185-186) reported two possible cases from Site 37 in Sremska Mitrovica, dated into the $10^{\text {th }}-12^{\text {th }}$ century.

As we can see, cases of tuberculosis found on skeletal remains are quite rare in Serbia and often come from a series with a very large number of deceased individuals. It is all the more surprising that there were as many as two cases on Margum/Morava, among such a limited number of individuals. If we add to this the post-traumatic infection observed in one individual, growth delay (1) and signs of nonspecific physiological stress (3), as well as numerous indicators of hard physical work, we can conclude that living conditions in medieval Margum/ Morava were very challenging.

Although this is just a small-scale study and thus not suitable for population comparison, it yielded some important results. We hope that this was only a pilot study and that future researches at this site will also include anthropological analyses so that the results published here will be complemented by more extensive studies.

\section{Conclusion}

This paper presents an anthropological analysis of eight individuals originating from the archaeological site of Margum/Morava, from the Medieval period. Although the number of individuals analysed in this paper is too small to allow us to draw any serious conclusions about those populations, it yielded exciting results regarding the health and diseases of the inhabitant of Margum/ 
Morava. Among the observed health problems, dental diseases and changes due to intense physical work were very frequent, followed by poorly repaired fractures, metabolic diseases and osteoarthrosis. Certainly, the most interesting are two possible cases of tuberculosis, from two different periods. Although tuberculosis has been one of the most common and deadly diseases in human history, its occurrence is most closely associated with modern times and the emergence of cities. In addition, tuberculosis most commonly attacks the soft tissue and leaves traces on the bone only in a small number of cases. On the territory of Serbia, up to now, only few cases were found and none of them in Eastern Serbia. Therefore, such a finding can be considered very valuable and rare.

We hope that this and similar studies will help us understand the importance and the necessity of anthropology above all, as well as the need that every archaeological excavation of a necropolis be accompanied by subsequent anthropological analyses. It is only this way, through cooperation and multidisciplinarity, that we can get a broader picture of the life conditions of past populations.

\section{REFERENCES}

Aggrawal, N.D., Kaur, R., Kumar, S. and Mathur, D. N. 1979. A study of changes in the spine in weight lifters and other athletes. British Journal of Sports Medicine 13(2): $58-61$.

Al Qahtani, S. J. 2012. The London Atlas: developing an atlas of tooth development and testing its quality and performance measures. Doctoral dissertation, Queen Mary University of London.

Anderson, A. S. and Loeser, R. F. 2010. Why is osteoarthritis an age-related disease? Best practice \& research Clinical rheumatology 24(1): 15-26.

Ansari, S., Amanullah, M. F., Ahmad, K., and Rauniyar, R. K. 2013. Pott's spine: diagnostic imaging modalities and technology advancements. North American journal of medical sciences 5(7): 404.

Бајаловић-Хаџи Пешић, М. 1984. Накит VIII-XVIII века у Музеју града Београда. Београд: Музеј града Београда, 1984.

Baxarias, J. and Herrerín, J. 2008. The handbook atlas of paleopathology. Barcelona: Libros Pórtico.

Benoist, M. 2003. Natural history of the aging spine. European Spine Journal 12 (2): S86-S89.

Bikić, V., Špehar, P., Bugarski, I., Branković, T. 2012. Arheološka istraživanja Marguma/Morave u 2011. godini, Arheologija u Srbiji. Beograd: Projekti Arheološkog instituta u 2011. godini

Bonfini, A. 1543. Rerum Ungaricarum decades tres nunc demum industria Martini, Basileae: Oporion. 
Brooks, S. and Suchey, J. M. 1990. Skeletal age determination based on the os pubis: a comparison of the Acsádi-Nemeskéri and Suchey-Brooks methods. Human evolution 5(3): 227-238.

Brothwell, D.R. 1981. Digging up bones: the excavation, treatment, and study of human skeletal remains. Cornell: University Press.

Bruzek, J. 2002. A method for visual determination of sex, using the human hip bone. American Journal of Physical Anthropology 117(2): 157-168.

Bugarski, I. and Ivanišević, V. 2013. Migration period finds from Margum: a possible interpretation. A Nyíregyházi Jósa András Múzeum Évkönyve LV: 467-483.

Buikstra, J. E. and Mielke, J. H. 1985. Demography, diet, and health. The analysis of prehistoric diets 359: 422.

Buikstra, J. E. and Ubelaker, D. H. 1994. Standards for data collection from human skeletal remains. Arkansas: Archeological Survey Research Series.

Campillo, D. 2001. Introduccion a la paleopatologia. Barcelona: Bellaterra.

Capasso, L., Kennedy, K. A. R., and Wilczak, C. A. 1999. Atlas of Occupational Markers on Human. Teramo: Remains.

Cunningham, C., Scheuer, L. and Black, S. 2016. Developmental juvenile osteology. Cambridge: Academic press.

Ćirić, G. 2016. Rimski novčići u ženskim grobovima sa teritorije Srbije: mogućnost interpretacije, Etnoantropološki problemi, n. s. god. 11 sv. 3.

Davis, A. L. 2000. A historical perspective on tuberculosis and its control. In Tuberculosis: a comprehensive international approach, 2nd ed, edited by: L. B. Reichman, E. S. Hershfield, 3-54. New York: Marcel Dekker.

Dlamini, N. and Morris, A.G. 2005. An investigation of the frequency of squatting facets in later stone age foragers from South Africa. International Journal of Osteoarchaeology 15(5): 371-376.

Djurić-Srejić, M. and Roberts, C. 2001. Palaeopathological evidence of infectious disease in skeletal populations from later medieval Serbia. International Journal of Osteoarchaeology 11(5), 311-320.

Farkas, G., Marcsik, A., Vekony, L. 1976, Vertebral deformation in the Avar skeletal material, Anthropologie 14, 231-233.

Ferembach, D., Schwidetzky, I., and Stloukal, M. 1980. Recommendations for age and sex diagnosis of skeletons. Journal of Human Evolution 9: 517-549.

Grmek, M. 1970. Medicinska enciklopedija. Jugoslovenski leksikografski zavod: Zagreb. Herrerín, J., Sarkic, N. Dinarés, R. 2018. Patología vertebral antemortem en los individuos exhumados en las fosas de la Guerra Civil en Calera y Chozas (Toledo). Proceedings Book of 5a reunión científica de Asociación Española de Antropología y Odontología Forense. July 2013, Verin, Spain, 134-146.

Huether, S.E. and McCance, K. L. 2016. Study Guide for Understanding Pathophysiology-E-Book. Elsevier Health Sciences. https://www.elsevier.com/books/understandingpathophysiology/huether/978-0-323-35409-7 (Date of Access 18. 04. 2020.) 
Иванишевић, В. и Бугарски, И. 2012. Примена LiDAR технологије у анализи топографије Маргума/Мораве и Кулича. Старинар LXII: 239-255.

Јовановић, А. и Цуњак, М. 1994. Археолошка истраживања у Дубравици (античком Маргуму) током 1989. и 1990. године, Саопштења 26: 107-122.

Kanitz, F. 1892. Römische Studien in Serbien. Der Donau-Grenzwall, das Strassennetz, die Städte, Castelle, Denkmale, Theremen und Bergwerke zur Römerzeit im Königreiche Serbien.

Khoo, L. T., Mikawa, K. and Fessler, R. G. 2003. A surgical revisitation of Pott distemper of the spine. The Spine Journal, 3(2): 130-145.

Kuczmarski, R. J., Ogden, C. L., Guo, S. S., Grummer-Strawn, L. M., Flegal, K. M., Mei, Z., Wei, R., Curtin, L. R., Roche, A. F., and Johnson, C. L. 2000. Growth Charts for the United States: methods and development. Hyattsville: DHSS Publication.

Lovász, G., Pálfi, G., Marcsik, A., Pósa, A., Neparáczky, E., Molnár, E. 2010. Skeletal manifestation of tuberculosis in a late medieval anthropological series from Serbia. Acta Biologica Szegediensis, 54(2), 83-91.

Lovejoy, C. O., Meindl, R. S., Pryzbeck, T. R. and Mensforth, R. P. 1985. Chronological metamorphosis of the auricular surface of the ilium: a new method for the determination of adult skeletal age at death. American journal of physical anthropology 68(1): 15-28.

Lovell, N.C. 2008. Analysis and interpretation of skeletal trauma. In Biological anthropology of the human skeleton, edited by Anne Katzenberg and Shelley Saunders, 341386. New Jersey: Wiley-Liss.

Мано-Зиси, Ђ. Марић, Р. и Гарашанин, М. 1950. Ископавање на Орашју. Претходни извештај о радовима у 1947 години, Старинар I: 143-165.

Марић, Р. 1951 - Ископавање на Орашју. Претходни извештај о радовима у 1948 и 1949 години, Старинар II: 113-132.

Mariotti, V., Facchini, F. and Belcastro, M. G. 2007. The study of entheses: proposal of a standardised scoring method for twenty-three entheses of the postcranial skeleton. Collegium antropologicum 31(1): 291-313.

Matos, V. and Santos, A. L. 2006. On the trail of pulmonary tuberculosis based on rib lesions: Results from the human identified skeletal collection from the Museu Bocage (Lisbon, Portugal). American Journal of Physical Anthropology: The Official Publication of the American Association of Physical Anthropologists 130(2): 190-200.

Младеновић, Б. и Јацановић, Д. 2002. Насеља Браничева. Пожаревац: COTOS.

Miladinović Radmilović, N. 2012, Analysis of human osteological material from the eastern part of site no. 37 in Sremska Mitrovica, Starinar 62, 181-204.

Mirković, M. 1986. Inscriptions de la Mésie Supérieure II: Viminacium et Margum. Beograd: RO Avala.

Mirković, M. 1968. Rimski gradovi na Dunavu u Gornjoj Meziji, Beograd: Arheološko društvo Jugoslavije (edicija "Disertacije").

Pearson, K. 1899. On the reconstruction of the stature of prehistoric races. Philosophical Transactions of the Royal Society of London 192: 169-244. 
Phillips, S. M. 2003. Worked to the bone: the biomechanical consequences of 'labor therapy' at a nineteenth century asylum. In Human Biologists in the Archives: Demography, Health, Nutrition and Genetics in Historical Populations, edited by D. Ann Herring, Alan C. Swedlund, 96-129. Cambridge: University Press.

Пириватрић, С. 1997. Византијска тема Морава и „Моравије“ Константина VII Порфирогенита, Зборник радова Византолошког института 36, Београд 1997, 173-201.

Roberts, C. and Manchester, K. 1995. The Archaeology of Disease. 2nd edition. Gloucester: Sutton Publishing.

Scheuer, L., and Black, S. 2004. The juvenile skeleton. Amsterdam: Elsevier.

Shapiro, F. 2001. Coxa vara in developmental and acquired abnormalities of the femur. Pediatric orthopedic deformities: basic science, diagnosis and treatment, 1st edn. Florida Academic Press: Miami.

Sretenovitch D. 1922. La tuberculose en Serbie, These pour le doctorat de L'Universite de Bordeaux.

Steckel, R. H., Larsen, C. S., Sciulli, P. W. and Walker, P. L. 2006. Data collection codebook. The global history of health project, 1-41.

Шпехар, П. 2007. Средњовековни налази из области Браничева, Гласник Српског археолошког друштва 23, Београд 2007, 363-390.

Viswanathan, V. K., \& Subramanian, S. 2019. Pott Disease (Tuberculous Spondylitis), 925-927. Treasure Island (FL): StatPearls Publishing.

Waldron, T. 2008. Palaeopathology. Cambridge: University Press.

Walker, P. L. 2005. Greater sciatic notch morphology: sex, age, and population differences. American Journal of Physical Anthropology 127(4): 385-391.

Walker, P. L., Johnson, J. R. and Lambert, P. M. 1988. Age and sex biases in the preservation of human skeletal remains. American Journal of Physical Anthropology 76(2): 183-188. 


\title{
Наташа Шаркић \\ OSTEO Research, Шпанија \\ Теодора Бранковић
}

Народни музеј Пожаревац, Србија

\section{АНТРОПОЛОШКА И ПАЛЕОПАТОЛОШКА АНАЛИЗА СКЕЛЕТНИХ ОСТАТАКА СА ЛОКАЛИТЕТА МАРГУМ/МОРАВА (ПОЖАРЕВАЦ, СРБИЈА), СРЕДЫИ ВЕК - РЕЗУЛТАТИ ИСКОПАВАЫА 2011}

\begin{abstract}
Кључне речи: метаболичке болести, инфекција, дентално здравље, окупациони стрес, ТБЦ, Потова болест, туберкулозни спондилитис
\end{abstract}

Археолошко налазиште Маргум, на ушћу Велике Мораве у Дунав, било је важна стратешка тачка, те је стога било насељено још у неолиту. Ово је прва антрополошка анализа до сада изведена на материјалу са Маргума, мада је сам локалитет археолошки истраживан од средине прошлог века, и пронађени су многи гробови из бронзаног и римског доба, Сеобе народа, византијског периода и средњег века.

Ако се има у виду да археолошки материјал није публикован, да су гробови ископани 2011. на Великим термама и Некропли углавном без прилога, као и да се ради о малом узорку, њихово датирање је отежано. Са потеза Великих терми обрађена су два гроба, за које можемо претпоставити да представљају део средњовековне некрополе ископаване 2004. године. ${ }^{7} \mathrm{Ha}$ основу ситуације констатоване на терену можемо их сврстати у два хоризонта становања, то јест у овом случају и два хоризонта сахрањивања, констатованих на овој локацији: гроб 3 у хоризонт 12. века, а гроб 7 у хоризонт 11. века. Датовање гробова на локацији Некрополе такође отежава недостатак прилога. Изузетак представља Г61, где је откривен тракасти прстен, чија типологија одговара датацији 10-13 век. Остали гробови ископани 2011. године, сиромашни гробним прилозима, такође су опредељени у средњи век на основу аналогије са гробовима ископаним 1989/90.

Антрополошка анализа објављена овде представља резултате ископавања из 2011. године. Иако је број анализираних гробова скроман - укупно 8 гробова из периода средњег века (за ову анализу смо узели у обзир само недевастиране гробове), добијени су узбудљиви резултати који ће нам помоћи да сазнамо више о условима живота на Маргуму. На основу уочених

\footnotetext{
${ }^{7}$ Резултати ископавања из 2004. нису публиковани.
} 
здравствених проблема, може се рећи да су денталне болести и промена на костима услед интензивног физичког рада биле веома честе. Поред тога, уочени су и лоше срасли преломи, метаболичке болести и остеоартроза. Свакако, најзанимљивија су два случаја туберкулозе из различитих периода. Иако је туберкулоза једна од најчешћих и најсмртоноснијих болести у историји човечанства, њена појава је најуже повезана са модерним временом и појавом градова. Уз то, туберкулоза најчешће напада мека ткива и само у малом броју случајева оставља трагове на костима. На територији Србије до сада је потврђено свега неколико случајева тубрекулозе у археолошком контексту, а ниједан од њих се не налази у источној Србији. Стога се такав налаз може сматрати веома вредним и ретким.

Надамо се да ће ова и сличне студије помоћи да се схвати важност физичке антропологије и да се препозна потреба да свако археолошко ископавање некрополе буде праћено антрополошким анализама. Само на тај начин, уз мултидисциплинарну сарадњу, можемо добити драгоцене податке о популацијама из прошлости. 